\title{
Pengukuran Pemenuhan Standar GMP dan WISE pada Pabrik Tahu Bandungan
}

\author{
Meta Prilelia Miasur ${ }^{* 1}$, Bambang Suhardi ${ }^{2}$, dan I Wayan Suletra ${ }^{3}$ \\ 1,2,3 Program Studi Teknik Industri, Fakultas Teknik, Universitas Sebelas Maret, \\ Jl. Ir. Sutami 36A Surakarta 57126 Indonesia \\ Email: metaprilelia@student.uns.ac.id¹, bambangsuhardi@staff.uns.ac.id ${ }^{2}$, suletra@staff.uns.ac.id ${ }^{3}$
}

\begin{abstract}
Abstrak
Pabrik Tahu Karya Mukti adalah Industri Rumah Tangga yang terletak di Desa Bandungan, kebersihan adalah hal yang kurang diperhatikan oleh pabrik. Observasi yang telah dilakukan menemukan bahwa dinding pabrik berdebu, langit-langit pabrik dipenuhi sarang laba-laba, lantai pabrik kotor, lubang angin berdebu dan dipenuhi sarang labalaba, serta sampah yang dibuang sembarangan di gudang sekam padi. Penelitian ini bertujuan untuk mengukur pemenuhan stándar GMP dan WISE pada Pabrik Tahu Karya Mukti serta memberikan usulan perbaikan pada elemen yang tidak sesuai sehingga diharapkan dapat membantu IRTP untuk mendapatkan SPP-IRT, menghasilkan produk yang aman dikonsumsi masyarakat serta mewujudkan kondisi kerja yang lebih aman, sehat, dan nyaman. Hasil dari penelitian yang telah dilakukan adalah ditemukan 12 kriteria yang tidak memenuhi standar GMP dan 3 kriteria yang mendapat usulan tindakan prioritas pada WISE. Usulan perbaikan diberikan kepada 12 kriteria GMP yang mendapat ketidaksesuaian kritis dan serius serta 3 kriteria WISE yang mendapat kategori usulan tindakan prioritas.
\end{abstract}

Kata kunci: IRTP, GMP, WISE

\section{Abstract}

Pabrik Tahu Karya Mukti a Home Industry located in Bandungan Village, the factory doesn't pay attention to hygiene. Observations that have been made found that the walls were dusty, the factory ceiling was filled with cobwebs, the factory ventilation were dusty and filled with cobwebs, as well as garbage dumped in the rice husk warehouse. This study aims to measure the fulfillment of GMP and WISE standards at Pabrik Tahu Karya Mukti and provide suggestions for improvement of elements that are expected to help IRTPs to obtain SPP-IRT, produce products that are safe for public consumption and create safer, healthier, and more comfortable working conditions. The result of the research that has been done is to find 12 criteria that do not meet GMP standards and 3 criteria that receive priority on WISE. Suggestions for improvement were given to 12 GMP criteria that received critical and serious discrepancies and 3 WISE criteria that received priority action categories.

Keywords: IRTP, GMP, WISE

\section{Pendahuluan}

Tahu merupakan salah satu makanan tradisional yang populer di Indonesia, pada tahun 2019 jumlah ratarata konsumsi tahu dalam seminggu sebesar $0,15 \mathrm{~kg}$ per kapita. Selain karena rasanya yang enak dan murah, tahu memiliki nilai gizi yang tinggi. Standar Nasional Indonesia (SNI) tahun 1998 menyatakan bahwa tahu adalah produk makanan yang memiliki bentuk padat dengan tekstur lunak yang terbuat dari kacang kedelai atau Glycine sp dengan melalui proses pengendapan dari protein dan penambahan bahan lain yang diizinkan.

Tahu dibuat dengan cara menggumpalkan protein kedelai menggunakan bahan penggumpal protein seperti asam cuka dan $\mathrm{CaSo}_{4}$. Kualitas dan kuantitas dari tahu dipengaruhi oleh varietas kedelai yang digunakan, proses pemanasan, tipe bahan koagulasi, serta tekanan dan suhu koagulasi. Tahu memiliki kadar protein sebesar 8-12\% dengan daya cerna yang sangat tinggi karena serat dan karbohidrat yang bersifat larut dalam air sebagian besar terbuang saat proses pembuangannya. Daya cerna tahu adalah sekitar 95\% dan aman dikonsumsi oleh segala umur, yaitu dari bayi hingga orang dewasa, termasuk orang dengan gangguan pencernaan (Shurtleff \& Aoyagi, 2001).

Kadar air serta protein tahu yang relatif tinggi masing-masing, yaitu $86 \%$ dan $8-12 \%$ membuat tahu bersifat mudah rusak sehingga hanya bertahan 1-2 hari pada suhu kamar. Setelah melewati 2 hari maka warna, aroma, dan tekstur tahu akan menyimpang serta rasanya menjadi asam. Tahu merupakan media yang cocok bagi pertumbuhan mikroorganisme pembusuk seperti bakteri dikarenakan komposisi nutrisinya (Koswara, 2011).

\footnotetext{
${ }^{*}$ Penulis korespondensi
} 
Kualitas tahu tahu ditentukan berdasarkan penampilannya, tahu yang berkualitas, yaitu bertekstur lembut, empuk, bentuknya seragam, saat dimakan terasa halus, dan berasa netral. Masyarakat umum mempersepsikan tahu dengan bentuk kotak, berwarna putih, memiliki permukaan yang halus, padat, tidak mudah pecah, dan tidak mengandung bahan pengawet. Merek dagang (trade mark) juga menentukan kualitas tahu karena merek dagang yang sudah terkenal pasti telah teruji kualitasnya. Tahu yang berkualitas memerlukan bahan baku biji kedelai berukuran besar, penggunaan air bersih, pemberian cuka yang tidak berlebihan, penggunaan biang tahu dengan perbandingan yang tepat, dan peralatan maupun lingkungan yang bersih (Mubaranto, 2016). Tahu memiliki banyak jenis seperti tahu putih, tahu kuning, tahu sutera, dan tahu kering (Sarwono \& Saragih, 2003).

Langkah-langkah dalam pembuatan tahu secara umum menurut Santoso tahun 1993 adalah sebagai berikut :

1. Penyortiran

2. Pencucian

3. Perendaman

4. Pengupasan

5. Penggilingan

6. Pemanasan

7. Penyaringan

8. Penggumpalan

9. Pencetakan

10. Pemotongan

Tahu pada umumnya diproduksi oleh Industri Rumah Tangga Pangan (IRTP) dimana IRTP termasuk dalam usaha mikro. Usaha Mikro, Kecil, dan Menengah (UMKM) menurut Undang-undang Nomor 20 Tahun 2008 didefinisikan sebagai usaha ekonomi produktif yang dimiliki oleh perorangan atau badan usaha yang bukan merupakan anak atau cabang perusahaan besar. UMKM merupakan usaha yang masih mendominasi dari keseluruhan usaha yang beroperasi di Indonesia. Menurut Badan Pusat Statistik, pada tahun 2018 jumlah UMKM mencapai 64 juta atau sekitar 99,9 persen dari keseluruhan usaha yang beroperasi di Indonesia.

Peran usaha mikro, kecil dan menengah (UMKM) menurut Kementerian Koperasi dan UKM tahun 2005 dalam perekonomian Indonesia paling tidak dapat dilihat dari :

1. Kedudukannya sebagai pemain utama dalam kegiatan ekonomi di berbagai sektor,

2. Penyedia lapangan kerja yang terbesar,

3. Pemain penting dalam pengembangan kegiatan ekonomi lokal dan pemberdayaan masyarakat,

4. Pencipta pasar baru dan sumber inovasi, serta

5. Sumbangannya dalam menjaga neraca pembayaran melalui kegiatan ekspor.

Produksi tahu dilakukan secara tradisional oleh IRTP dengan mutu produk yang dihasilkan belum berkualitas, hal ini disebabkan tidak adanya suatu sistem yang dapat menjaga produk untuk memenuhi standar yang telah ditetapkan. Mengacu pada Pasal 43 Peraturan Pemerintah Nomor 28 Tahun 2004 Tentang Keamanan, Mutu, dan Gizi Pangan mengamanatkan bahwa pangan olahan yang diproduksi oleh industri rumah tangga wajib memiliki Sertifikat Produksi Pangan Industri Rumah Tangga (SPP-IRT) yang diterbitkan oleh Bupati/Walikota dan Kepala Badan Pengawasan Obat dan Makanan (BPOM) menetapkan pedoman pemberian SPP-IRT. Keuntungan yang didapat jika memiliki SPPIRT adalah IRTP dapat memperluas jangkauan pasar secara legal terutama melalui toko-toko besar dan peningkatan kepercayaan konsumen.

Pabrik Tahu Karya Mukti adalah salah satu IRTP yang berlokasi di Bandungan, Kabupaten Semarang. Pabrik ini memiliki jumlah pekerja sebanyak 8 orang dan proses produksinya dilakukan secara tradisional. Pada Pabrik tahu Karya Mukti Bandungan, kebersihan adalah hal yang kurang diperhatikan, hal ini terlihat dari dinding pabrik yang berdebu, langit-langit pabrik dipenuhi sarang laba-laba, lantai pabrik yang kotor karena banyak sekam padi yang berceceran, lubang angin berdebu dan dipenuhi sarang laba-laba, serta sampah yang dibuang sembarangan di gudang sekam padi. Kondisi kerja yang kotor dapat menimbulkan kontaminasi pada tahu akibat debu dan kotoran yang masuk saat proses produksi.

Permasalahan tersebut menunjukkan bahwa Pabrik Tahu Karya Mukti Bandungan belum sesuai dengan standar Good Manufacturing Practices (GMP) yang telah ditetapkan BPOM sehingga tidak ada jaminan bahwa produk yang dihasilkan aman dikonsumsi masyarakat. Maka dari itu dilakukan pengukuran pemenuhan standar GMP dan Work Improvement in Small Enterprise (WISE) pada Pabrik Tahu Karya Mukti Bandungan sehingga akan didapatkan elemen-elemen yang harus diperbaiki dan diberikan usulan perbaikan. WISE akan menjadi supporting yang dapat mendorong IRTP untuk memenuhi standar GMP.

Good Manufacturing Practices (GMP) atau yang dikenal di Indonesia sebagai Cara Produksi Pangan yang Baik (CPPB) merupakan suatu pedoman cara memproduksi makanan dengan tujuan agar produsen memenuhi persyaratan-persyaratan yang telah ditentukan untuk menghasilkan produk makanan bermutu sesuai dengan tuntutan konsumen (Thaheer, 2005). Prinsip dasar dari GMP adalah bahwa mutu produk tidak hanya diuji pada produk akhir saja namun juga dibangun di dalam produk, artinya penjaminan mutu dilakukan dari awal hingga akhir dengan cara membuat produk dengan prosedur tertentu dalam kondisi yang sama kapanpun produk dibuat (Hermansyah, dkk, 2013).

Sedangkan WISE menekankan hubungan antara kondisi kerja yang baik untuk meningkatkan produktivitas dan memberikan arahan tentang pentingnya kerja sama antar pekerja untuk mencapai perubahan yang positif (Damarasri, dkk, 2013). WISE membantu UMKM meningkatkan kondisi kerja dan 
produktivitas dengan menggunakan teknik sederhana, efektif dan terjangkau yang memberikan manfaat langsung kepada pemilik dan pekerja (Islami \& Partiwi, 2013).

Damarasri, Partiwi, \& Gunawan (2013) meneliti penerapan GMP dan WISE pada usaha kecil dan menengah untuk pemenuhan standar kesehatan yang dilakukan di IRTP tempe dengan bantuan metode AHP. Kemudian Suhardi, Kadita, \& Laksono (2018) membahas perbaikan proses produksi dengan standar cara produksi pangan yang baik (CPPB) dan WISE pada industri kerupuk SALA menggunakan daftar periksa CPPB-WISE sebagai upaya perbaikan produksi dan pemenuhan standar untuk mendapatkan SPP-IRT, penelitian ini juga menggunakan metode AHP untuk mengolah datanya. Lalu Mairawati, Suhardi, \& Astuti (2019) mengevaluasi sistem kerja sesuai dengan standar CPPB-IRT, halal LPOM MUI, dan WISE pada perusahaan cake and bakery menggunakan bantuan metode Borda. Selanjutnya Suhardi, Wardani, \& Jauhari (2019) melakukan penelitian mengenai perbaikan proses produksi IKM XYZ berdasarkan kriteria CPPB-IRT, WISE dan Sistem Jaminan Halal dari Lembaga Pengkajian Pangan, Obat-obatan, dan Kosmetika Majelis Ulama Indonesia dengan bantuan metode Brainstorming

Penelitian ini akan mengukur tingkat pemenuhan standar GMP dan WISE pada Pabrik Tahu Karya Mukti Bandungan serta memberikan usulan perbaikan pada elemen yang mendapat ketidaksesuaian kritis dan serius pada GMP serta usulan tindakan prioritas pada WISE. Usulan perbaikan yang diberikan diharapkan dapat membantu IRTP untuk mendapatkan SPP-IRT, menghasilkan produk yang aman dikonsumsi masyarakat serta mewujudkan kondisi kerja yang lebih aman, sehat, dan nyaman.

\section{Metode Penelitian}

Terdapat beberapa tahapan penelitian yang dilakukan, tahap awal dalam penelitian ini adalah melakukan studi literatur dan studi lapangan. Studi lapangan dilakukan di Pabrik Tahu Karya Mukti Bandungan, Kabupaten Semarang, Jawa Tengah melalui observasi langsung serta wawancara kepada pemilik dan 7 orang karyawan pabrik. Setelah tahap studi literatur dan studi lapangan, tahap selanjutnya adalah identifikasi masalah, perumusan masalah, penetapan tujuan dan manfaat penelitian.

Kemudian masuk ke tahap pengumpulan data, pada tahap ini pengumpulan data didasarkan dari hasil observasi dan wawancara yang telah dilakukan pada tahap studi lapangan. Data yang diambil meliputi tata letak Pabrik Tahu Karya Mukti Bandungan, proses pembuatan tahu, dan pengukuran pemenuhan standar GMP dan WISE pada Pabrik Tahu Karya Mukti Bandungan. Tata letak Pabrik Tahu Karya Mukti digunakan untuk mengetahui ukuran ruang produksi, aliran produksi, dan rute transportasi pemindahan material. Data proses pembuatan tahu digunakan untuk mengetahui proses produksi yang dilakukan memenuhi standar GMP dan WISE atau tidak, hal ini dapat dilihat dari kebiasaan pekerja untuk mencuci tangan sebelum bekerja, penggunaan pakaian kerja saat bekerja, dan perilaku karyawan selama bekerja. Lalu kondisi awal Pabrik Tahu Karya Mukti Bandungan akan dibandingkan dengan pedoman GMP yang berisi kriteria-kriteria dari BPOM dan WISE dari International Labour Organization (ILO).

Setelah data tersebut dikumpulkan, tahap selanjutnya adalah pengolahan data. Pengolahan data terdiri dari rekapitulasi hasil pengukuran pemenuhan standar GMP-WISE dan usulan perbaikan pada Pabrik tahu Karya Mukti Bandungan. Pada rekapitulasi hasil pengukuran pemenuhan standar GMP-WISE, hasil evaluasi GMP dan WISE akan disusun secara terpisah yang terdiri dari subkriteria yang memiliki ketidaksesuaian kritis dan serius pada GMP serta usulan tindakan prioritas pada WISE. Usulan perbaikan akan diberikan pada subkriteria yang mendapatkan ketidaksesuaian kritis dan serius dari GMP serta subkriteria yang mendapatkan usulan tindakan prioritas dari WISE.

Tahap selanjutnya adalah analisis dan interpretasi hasil dari pengolahan data yang telah dilakukan sebelumnya. Tahap terakhir adalah menarik kesimpulan dari penelitian serta memberikan saran bagi penelitian selanjutnya.

\section{Hasil dan Pembahasan}

Pabrik Tahu Karya Mukti terletak di Desa Bandungan, pabrik ini memiliki luas bangunan sebesar $11,9 \mathrm{~m} \times 6,8 \mathrm{~m}$. Bangunan ini terdiri dari beberapa ruangan, yaitu gudang bahan baku kedelai, ruang penggilingan kedelai, ruang produksi tahu, ruang pemotongan tahu, ruang penggorengan tahu, dan kamar mandi. Lay out pabrik digunakan untuk membandingkan kondisi pabrik dengan standar GMP dan WISE, seperti luas pabrik, ukuran dan kondisi ruang produksi, aliran produksi, serta rute transportasi pemindahan material. Lay out Pabrik Tahu Karya Mukti Bandungan dapat dilihat pada Gambar 1 


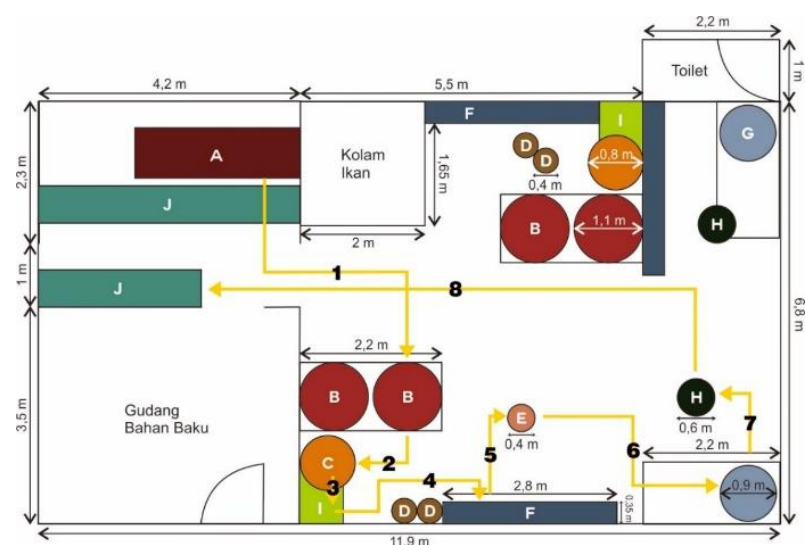

\begin{tabular}{|c|c|c|c|c|c|}
\hline Simbol & Keterangan & Simbol & Keterangan & Simbol & Keterangan \\
\hline A & Mesin Giling & E & $\begin{array}{c}\text { Tempat } \\
\text { Pemotongan }\end{array}$ & I & $\begin{array}{c}\text { Tempat } \\
\text { Pencetakan Tahu }\end{array}$ \\
\hline B & $\begin{array}{c}\text { Tempat } \\
\text { Perebusan }\end{array}$ & F & $\begin{array}{c}\text { Rak } \\
\text { Penyimpanan }\end{array}$ & J & $\begin{array}{c}\text { Tempat } \\
\text { Perendaman Tahu }\end{array}$ \\
\hline C & $\begin{array}{c}\text { Tempat } \\
\text { Penyaringan }\end{array}$ & C & $\begin{array}{c}\text { Tempat } \\
\text { Penggorengan }\end{array}$ & $\longrightarrow$ & $\begin{array}{c}\text { Alur Proses } \\
\text { Produksi }\end{array}$ \\
\hline D & $\begin{array}{c}\text { Drum Penampung } \\
\text { Biang Tahu }\end{array}$ & H & $\begin{array}{c}\text { Tempat } \\
\text { Menata Tahu }\end{array}$ & & \\
\hline
\end{tabular}

Gambar 1. Lay Out Pabrik Tahu Karya Mukti

Bahan baku dalam pembuatan tahu adalah kedelai sedangkan untuk bahan penolong adalah air dan biang tahu. Proses pembuatan tahu dilakukan oleh 8 orang pekerja yang terbagi dalam beberapa stasiun kerja. Peta Proses Operasi dari pembuatan tahu putih dapat dilihat pada gambar 2.

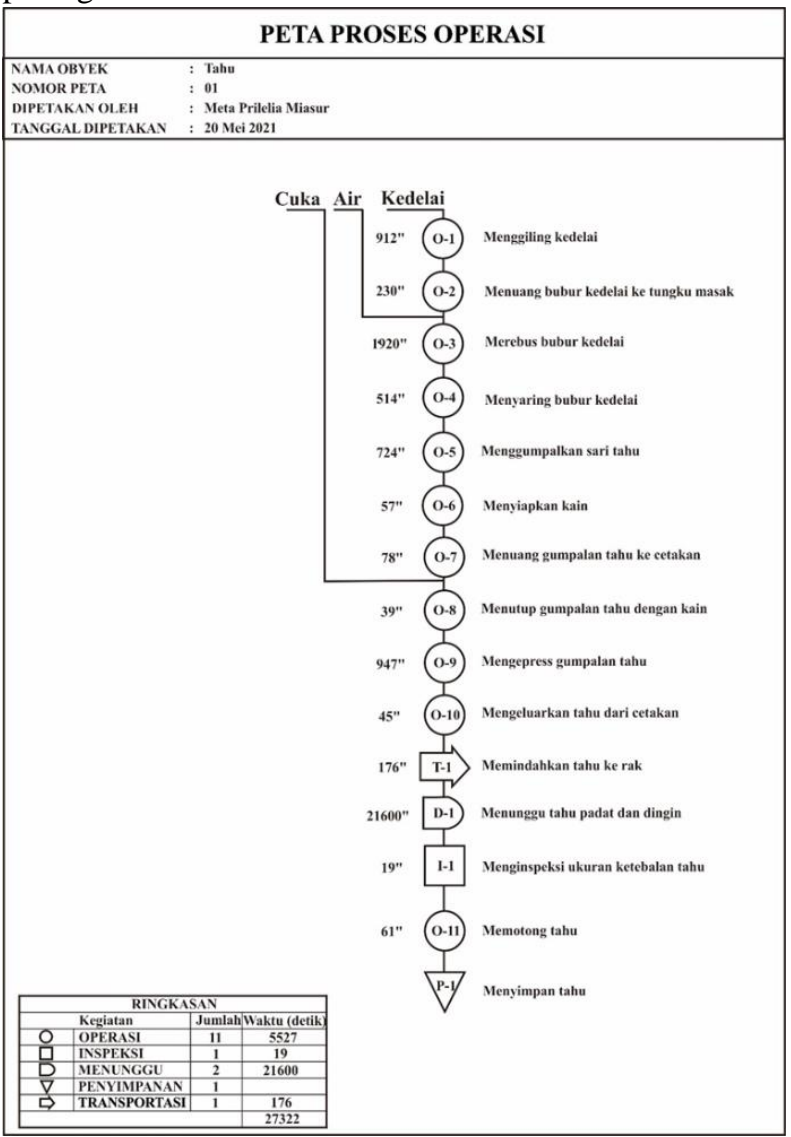

Gambar 2. Peta Proses Operasi Pembuatan Tahu

Kondisi saat ini pada Pabrik Tahu Karya Mukti Bandungan akan dievaluasi berdasarkan pedoman GMP dan WISE. Evaluasi dilakukan dengan cara memberikan penilaian pada daftar periksa GMP dan WISE sesuai dengan pedoman pengisian masing-masing. Hasil pengukuran pemenuhan standar GMP dan WISE yang telah dilakukan di Pabrik Tahu Karya Mukti Bandungan masing-masing akan direkap. Pada standar GMP diambil subkriteria yang mendapatkan penilaian kritis dan serius, lalu pada standar WISE diambil usulan tindakan yang menjadi prioritas. Rekapitulasi hasil pengukuran pemenuhan standar GMP-WISE dapat dilihat pada tabel 1 dan 2 .

Tabel 1. Rekapitulasi Hasil Pengukuran Pemenuhan Stándar GMP

\begin{tabular}{|c|c|c|c|}
\hline No & Kriteria & $\begin{array}{c}\text { Sub-Kriteria } \\
\end{array}$ & Penilai \\
\hline 1 & $\begin{array}{c}\text { Lokasi dan } \\
\text { Lingkungan Produksi }\end{array}$ & $\begin{array}{l}\text { Lokasi dan lingkungan IRTP tidak terawat, kotor, dan } \\
\text { berdebu }\end{array}$ & Peneliti \\
\hline \multirow{2}{*}{2} & Bangunan dan & $\begin{array}{l}\text { Lantai, dinding, dan langit-langit, tidak terawat, kotor, } \\
\text { berdebu, dan atau berlendir }\end{array}$ & Peneliti \\
\hline & Fasilitas & $\begin{array}{l}\text { Ventilasi, pintu, dan jendela tidak terawat, kotor, dan } \\
\text { berdebu }\end{array}$ & Peneliti \\
\hline \multirow{3}{*}{3} & \multirow{3}{*}{$\begin{array}{r}\text { Fasilitas dan Kegiatan } \\
\text { Higiene dan Sanitasi }\end{array}$} & $\begin{array}{l}\text { Tidak tersedia sarana cuci tangan lengkap dengan } \\
\text { sabun dan alat pengering tangan }\end{array}$ & Peneliti \\
\hline & & Tersedia tempat pembuangan sampah terutup & Peneliti \\
\hline & & $\begin{array}{l}\text { Saran toilet/jamban kotor tidak terawat dan terbuka ke } \\
\text { ruang produksi }\end{array}$ & Peneliti \\
\hline \multirow[t]{2}{*}{4} & \multirow[t]{2}{*}{$\begin{array}{l}\text { Kesehatan dan } \\
\text { Higiene Karyawan }\end{array}$} & $\begin{array}{l}\text { Karyawan tidak mencuci tangan dengan bersih sewaktu } \\
\text { memulai mengolah pangan, sesudah menangani bahan } \\
\text { mentah, atau bahan/alat yang kotor, dan sesudah ke luar } \\
\text { dari toilet/jamban }\end{array}$ & Peneliti \\
\hline & & $\begin{array}{l}\text { Karyawan di bagian produksi pangan tidak mengenakan } \\
\text { pakaian kerja dan/atau mengenakan perhiasan }\end{array}$ & Peneliti \\
\hline \multirow[b]{2}{*}{5} & $\begin{array}{l}\text { Pemeliharaan dan } \\
\text { Pemai }\end{array}$ & $\begin{array}{l}\text { Program higiene dan sanitasi tidak dilakukan secara } \\
\text { berkala }\end{array}$ & Peneliti \\
\hline & $\begin{array}{l}\text { Program Higiene dan } \\
\text { Sanitasi }\end{array}$ & $\begin{array}{l}\text { Hewan peliharaan terlihat berkeliaran di sekitar dan di } \\
\text { dalam ruang produksi pangan }\end{array}$ & Peneliti \\
\hline 6 & Penyimpanan & $\begin{array}{l}\text { Peralatan yang bersih disimpan di tempat yang kotor } \\
\text { IRTP tidak memiliki catatan: menggunakan bahan baku }\end{array}$ & Peneliti \\
\hline \multirow{4}{*}{7} & \multirow{4}{*}{ Pengendalian Proses } & $\begin{array}{l}\text { yang sudah rusak, bahan tambahan pangan,bahan } \\
\text { berbahaya dan bahan tambahan pangan yang tidak } \\
\text { sesuai dengan persyaratan penggunaannya }\end{array}$ & Peneliti \\
\hline & & $\begin{array}{l}\text { IRTP tidak mempunyai atau tidak mengikuti bagan alir } \\
\text { produksi pangan. }\end{array}$ & Peneliti \\
\hline & & BTP tidak diberi penandaan dengan benar & Peneliti \\
\hline & & $\begin{array}{l}\text { Alat ukur / timbangan untuk mengukur / menimbang } \\
\text { BTP tidak tersedia atau tidak teliti. }\end{array}$ & Peneliti \\
\hline 8 & Pelabelan Pangan & $\begin{array}{l}\text { Label pangan tidak mencantumkan nama produk, daftar } \\
\text { bahan yang digunakan, berat bersih/isi bersih, nama dan } \\
\text { alamat IRTP, masa kedaluwarsa, kode produksi dan } \\
\text { nomor P-IRT }\end{array}$ & Peneliti \\
\hline \multirow{3}{*}{9} & \multirow{3}{*}{$\begin{array}{l}\text { Pengawasan oleh } \\
\text { Penanggung Jawab }\end{array}$} & $\begin{array}{l}\text { Label mencantumkan klaim kesehatan atau klaim gizi } \\
\text { IRTP tidak mempunyai penanggung jawab yang }\end{array}$ & Peneliti \\
\hline & & $\begin{array}{l}\text { memiliki Sertifikat Penyuluhan Keamanan Pangan } \\
\text { (PKP) }\end{array}$ & Peneliti \\
\hline & & $\begin{array}{l}\text { IRTP tidak melakukan pengawasan internal secara } \\
\text { rutin, termasuk monitoring dan tindakan koreksi }\end{array}$ & Peneliti \\
\hline 10 & Penarikan Produk & $\begin{array}{l}\text { Pemilik IRTP tidak melakukan penarikan produk } \\
\text { pangan yang tidak aman }\end{array}$ & Peneliti \\
\hline 11 & $\begin{array}{l}\text { Pencatatan dan } \\
\text { Dokumentasi }\end{array}$ & IRTP tidak memiliki dokumen produksi & Peneliti \\
\hline 12 & Pelathan Karyawan & $\begin{array}{l}\text { IRTP tidak memiliki program pelatihan keamanan } \\
\text { pangan untuk karyawan }\end{array}$ & Peneliti \\
\hline
\end{tabular}

Keterangan tiap warna

Kritis

Serius

Tabel 2. Rekapitulasi Hasil Pengukuran Pemenuhan Stándar WISE

\begin{tabular}{cclc}
\hline No & Kriteria & \multicolumn{1}{c}{ Sub-Kriteria Prioritas } & Penilai \\
\hline \multirow{2}{*}{1} & Keamanan Mesin & Memeriksa, membersihkan, dan memelihara mesin- & Peneliti \& \\
& Produktif & mesin, termasuk kabel listrik secara teratur & Pemilik IRTP \\
& & Menyediakan perlengkapan pelindung pribadi yang & Peneliti \& \\
& Fasilitas & memberikan perlindungan yang memadai & Pemilik IRTP \\
& Kesejahteraan & $\begin{array}{l}\text { Menyediakan peralatan pertolongan pertama (P3K) dan } \\
\text { melatih petugas P3K yang memenuhi syarat }\end{array}$ & Peneliti \& \\
& & Pemilik IRTP \\
& & Menetapkan kebijakan K3 dan menyediakan pelatihan & Peneliti \& \\
3 & Organisasi Pekerjaan & keselamatan dan kesehatan yang memadai bagi semua \\
& & & Pemilik IRTP \\
\hline
\end{tabular}

Dari 14 kriteria GMP, 12 diantaranya mengandung subkriteria dengan ketidaksesuaian kritis dan serius. Kriteria-kriteria tersebut adalah lokasi dan lingkungan 
produksi, bangunan dan fasilitas, fasilitas dan kegiatan higiene dan sanitasi, kesehatan dan higiene karyawan, pemeliharaan dan program higiene dan sanitasi, penyimpanan, pengendalian proses, pelabelan pangan, pengawasan oleh penanggung jawab, penarikan produk, pencatatan dan dokumentasi, serta pelatihan karyawan. Terdapat 22 subkriteria yang mendapatkan ketidaksesuaian kritis dan serius.

Sedangkan dari 8 kriteria WISE, 3 diantaranya mengandung subkriteria dengan usulan tindakan prioritas. Kriteria-kriteria tersebut adalah keamanan mesin produktif, fasilitas kesejahteraan, dan organisasi pekerjaan. Terdapat 4 subkriteria yang mendapatkan usulan tindakan prioritas.

Usulan perbaikan diberikan pada subkriteria yang mendapat ketidaksesuaian kritis dan serius pada GMP serta subkriteria yang mendapat usulan tindakan prioritas pada WISE.

Pada GMP terdapat 12 kriteria yang mengandung subkriteria dengan ketidaksesuaian. Kriteria-kriteria tersebut adalah :

1. Lokasi dan lingkungan produksi

Terdapat 1 subkriteria yang mendapatkan ketidaksesuaian serius, yaitu lokasi dan lingkungan IRTP tidak terawat, kotor, dan berdebu diakibatkan oleh abu sisa pembakaran yang tidak dibersihkan sehingga membuat lingkungan pabrik menjadi kotor. Usulan perbaikan yang diberikan adalah membuat monitoring kebersihan dan menempelkan pengingat di dinding pabrik. Tujuan dari pembuatan monitoring kebersihan ini adalah untuk memastikan setiap area kerja yang ada dibersihkan secara terjadwal sehingga tidak menimbulkan penumpukan kotoran dan debu di area kerja. Monitoring dilakukan oleh pemilik pabrik dengan cara memberikan tanda centang pada tabel monitoring kebersihan. Pengingat ditempelkan pada dinding pabrik agar seluruh pekerja dapat melihat dan mengingat jadwal bersih-bersih. Kegiatan bersih-bersih dilakukan tiap dua minggu sekali pada hari Kamis. Contoh pengingat berupa slogan dan monitoring kebersihan dapat dilihat pada gambar 3 dan gambar 4 .

\section{KAMIS RAPIH
KAMIS BERSIH}

Gambar 4. Slogan

\section{Bangunan dan fasilitas}

Terdapat 2 subkriteria yang mendapatkan ketidaksesuaian serius, yaitu lantai, dinding, dan langitlangit tidak terawat, kotor, berdebu, dan atau berlendir serta ventilasi, pintu, dan jendela tidak terawat, kotor, dan berdebu. Kondisi lantai pada bagian penyaringan dan pencetakan tahu selalu basah dan lembab sehingga muncul lendir, ditambah permukaan yang tidak rata sehingga semakin sulit dibersihkan karena banyak sudut. Dinding serta langit-langit kotor dan berdebu akibat abu sisa pembakaran yang tidak pernah dibersihkan. Ventilasi kotor dan berdebu, lalu pabrik tidak memiliki pintu sehingga debu mudah masuk dan berpotensi mencemari pangan. Usulan perbaikan yang diberikan adalah membuat monitoring kebersihan dan menempelkan pengingat di dinding pabrik. Kegiatan membersihkan lantai dapat dilakukan setiap selesai bekerja untuk mencegah lendir muncul akibat air sisa produksi, sedangkan kegiatan membersihkan dinding, langit-langit, dan ventilasi dapat dilakukan bersamaan dengan kegiatan membersihkan area kerja, yaitu tiap dua minggu sekali pada hari Kamis. Usulan perbaikan monitoring kebersihan dan pengingat dapat dilihat pada gambar 3 dan gambar 4 .

3. Fasilitas dan kegiatan higiene dan sanitasi

Terdapat 1 subkriteria yang mendapatkan ketidaksesuaian kritis, yaitu tidak tersedia tempat pembuangan sampah tertutup. Kemudian ada 2 subkriteria yang mendapatkan ketidaksesuaian serius, yaitu tidak tersedia saran cuci tangan lengkap dengan sabun dan alat pengering tangan serta saran toilet/jamban kotor, tidak terawat, dan terbuka ke ruang produksi.

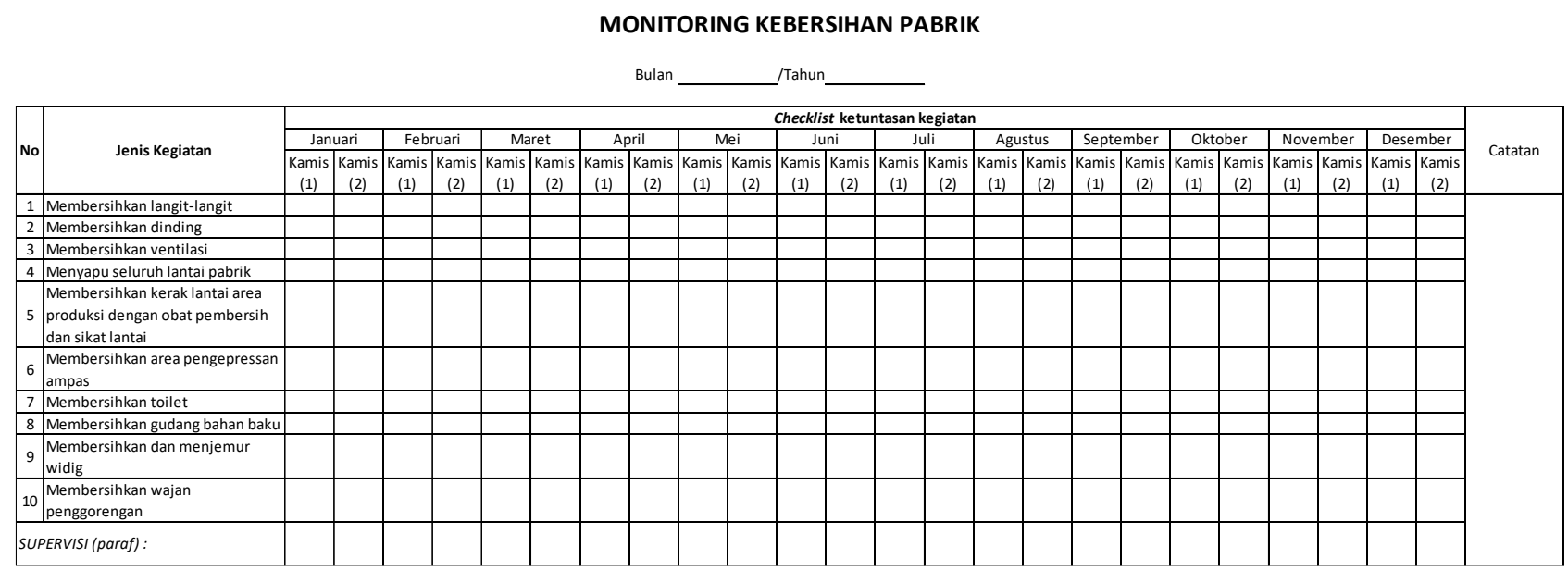

Gambar 3. Monitoring Kebersihan 
Pabrik tidak menyediakan tempat pembuangan sampah tertutup sehingga sampah dibuang begitu saja di gudang sekam padi yang selanjutnya akan digunakan sebagai bahan bakar. Pabrik juga tidak memiliki wastafel khusus untuk mencuci tangan dan kondisi pintu toilet yang tidak ditutup rapat. Usulan perbaikan yang diberikan adalah menyediakan sarana cuci tangan lengkap serta menempelkan prosedur mencuci tangan yang benar, lalu menyediakan tempat sampah tertutup, dan menempel tanda peringatan pada pintu toilet yang berisi perintah menutup pintu toilet setiap selesai digunakan. Prosedur cuci tangan yang benar, tempat sampah tertutup, dan tanda peringatan pada pintu toilet dapat dilihat pada gambar 5, 6, dan 7 .

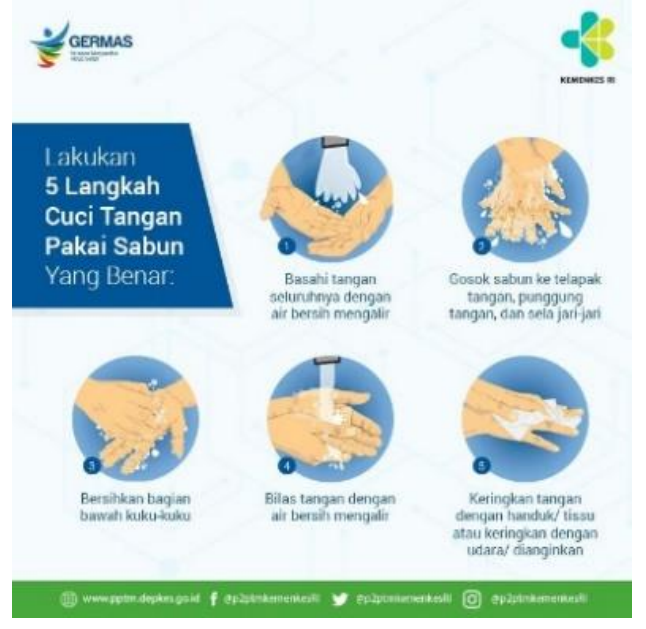

Gambar 5. Prosedur Mencuci Tangan yang Benar
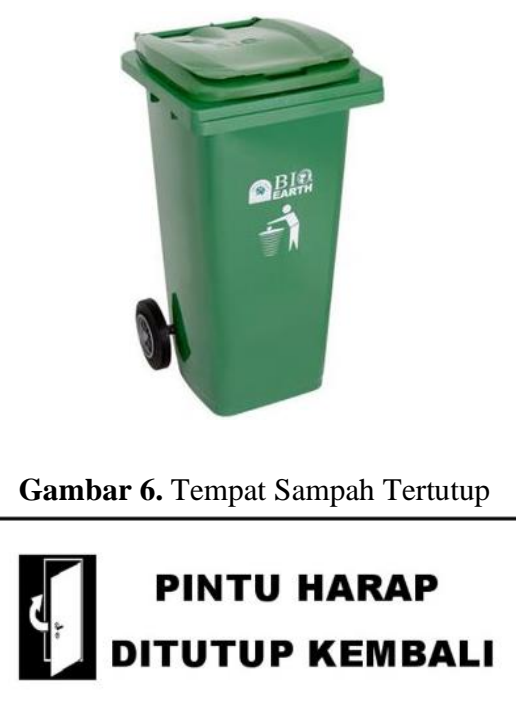

Gambar 7. Tanda Peringatan pada Pintu Toilet

4. Kesehatan dan higiene karyawan

Terdapat 1 subkriteria yang mendapatkan ketidaksesuaian kritis, yaitu karyawan tidak mencuci tangan dengan bersih sewaktu memulai mengolah pangan, sesudah menangani bahan mentah, atau bahan/alat yang kotor, dan sesudah keluar dari toilet/jamban. Kemudian ada 1 subkriteria yang mendapatkan ketidaksesuaian serius, yaitu karyawan di bagian produksi pangan tidak mengenakan pakaian kerja dan/atau mengenakan perhiasan. Pabrik tidak memiliki program cuci tangan sebelum melakukan pekerjaan, sesudah menangani bahan mentah, dan sesudah keluar dari toilet. Lalu pabrik juga tidak memiliki seragam khusus yang digunakan saat bekerja sehingga pekerja memakai baju bebas. Usulan perbaikan yang diberikan adalah memberlakukan peraturan wajib cuci tangan sebelum mengolah bubur kedelai dan setelah keluar dari toilet, kemudian memberlakukan peraturan bagi pekerja untuk menggunakan pakaian kerja lengkap seperti seragam kerja, celemek, penutup kepala, penutup hidung dan mulut, sarung tangan, serta sepatu boots. Tujuan dari kedua usulan tersebut adalah untuk mencegah kontaminasi produk sehingga produk aman sampai ke tangan konsumen dan melindungi pekerja. Peraturan wajib cuci tangan serta pakaian kerja dapat ditempelkan di dinding. Tanda wajib cuci tangan dan pakaian kerja dapat dilihat pada gambar 8 dan 9 .

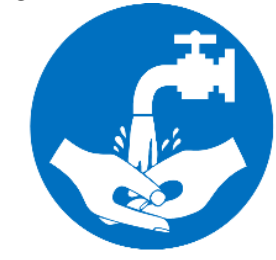

\section{CUCI TANGAN \\ SEBELUM DAN \\ SESUDAH BEKERJA}

Gambar 8. Tanda Wajib Cuci Tangan
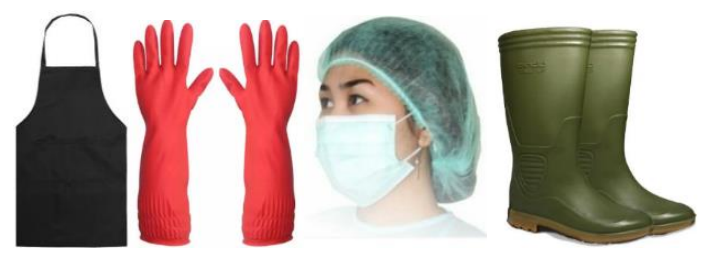

Gambar 9. Pakaian Kerja

5. Pemeliharaan dan program higiene dan sanitasi

Terdapat 1 subkriteria yang mendapatkan ketidaksesuaian kritis, yaitu hewan peliharaan terlihat berkeliaran di sekitar dan di dalam ruang produksi pangan. Kemudian ada 1 subkriteria yang mendapatkan ketidaksesuaian serius, yaitu program higiene dan sanitasi tidak dilakukan secara berkala. Hewan peliharaan seperti kucing terlihat berkeliaran dengan bebas di dalam pabrik dan melewati ruang produksi. Lalu program higiene dan sanitasi tidak dilakukan secara berkala karena pabrik tidak memiliki jadwal untuk melakukan pembersihan area kerja, tidak ada prosedur pembersihan dan sanitasi, serta tidak ada penanganan limbah sisa produksi. Usulan perbaikan yang diberikan adalah membuat program higiene dan sanitasi yang dapat dilakukan secara rutin, dan menutup tungku masak dengan triplek atau papan untuk mencegah kontaminasi dari hewan peliharaan yang berkeliaran karena sulitnya 
membatasi pergerakan hewan peliharaan. Contoh penggunaan triplek untuk menutup tungku masak dapat dilihat pada gambar 10 .

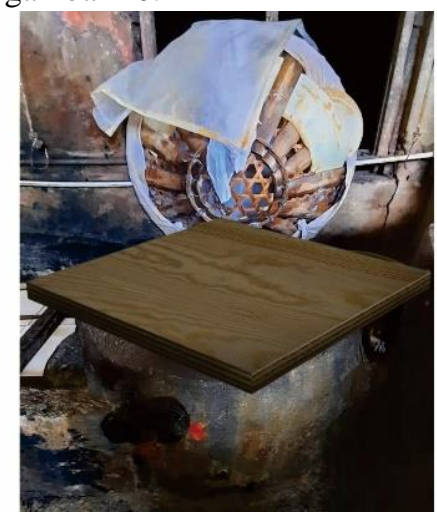

Gambar 10. Triplek untuk Menutup Tungku Masak

6. Penyimpanan

Terdapat 1 subkriteria yang mendapatkan ketidaksesuaian kritis, yaitu peralatan yang bersih disimpan di tempat yang kotor. Pabrik tidak memiliki ruang penyimpanan khusus untuk menyimpan alat-alat produksi yang sudah dibersihkan sehingga menyebabkan peralatan terkena debu serta abu sisa pembakaran sekam padi. Usulan perbaikan yang diberikan adalah pabrik menyediakan ruang penyimpanan yang bersih dan bebas dari kontaminasi abu, pabrik memiliki gudang bersih yang dapat digunakan untuk meletakkan peralatan produksi yang sudah dibersihkan setelah selesai bekerja.

7. Pengendalian proses

Terdapat 1 subkriteria yang mendapatkan ketidaksesuaian kritis, yaitu IRTP tidak memiliki catatan; menggunakan bahan baku yang sudah rusak, bahan berbahaya, dan bahan tambahan pangan yang tidak sesuai dengan persyaratan penggunaannya. Kemudian ada 3 subkriteria yang mendapatkan ketidaksesuaian serius, yaitu IRTP tidak mempunyai atau tidak mengikuti bagan alir produksi pangan, Bahan Tambahan Pangan (BTP) tidak diberi penandaan dengan benar, dan alat ukur/timbangan untuk mengukur/menimbang BTP tidak tersedia atau tidak teliti. Pabrik tidak pernah mencatat bahan baku yang rusak serta banyaknya penggunaan BTP untuk produk pangan. Tidak terdapat bagan alir produksi pangan di pabrik serta BTP tidak ditandai dengan benar dan penggunaannya pada produk tidak diukur secara teliti sehingga hanya berdasarkan perkiraan pekerja saja. Usulan perbaikan yang diberikan adalah pemilik membuat catatan penggunaan bahan tambahan pangan sehingga dapat diketahui jumlah penggunaannya, lalu membuat bagan alir produksi tahu yang dapat dijalankan sebagai standar prosedur dalam membuat tahu, wadah bahan tambahan pangan diberi tanda menggunakan spidol permanen, dan menyediakan alat ukur untuk mengukur penggunaan bahan tambahan pangan sehingga jumlahnya konsisten untuk setiap masakan. Bagan alir produksi tahu dan alat ukur BTP dapat dilihat pada gambar 11 dan 12 .

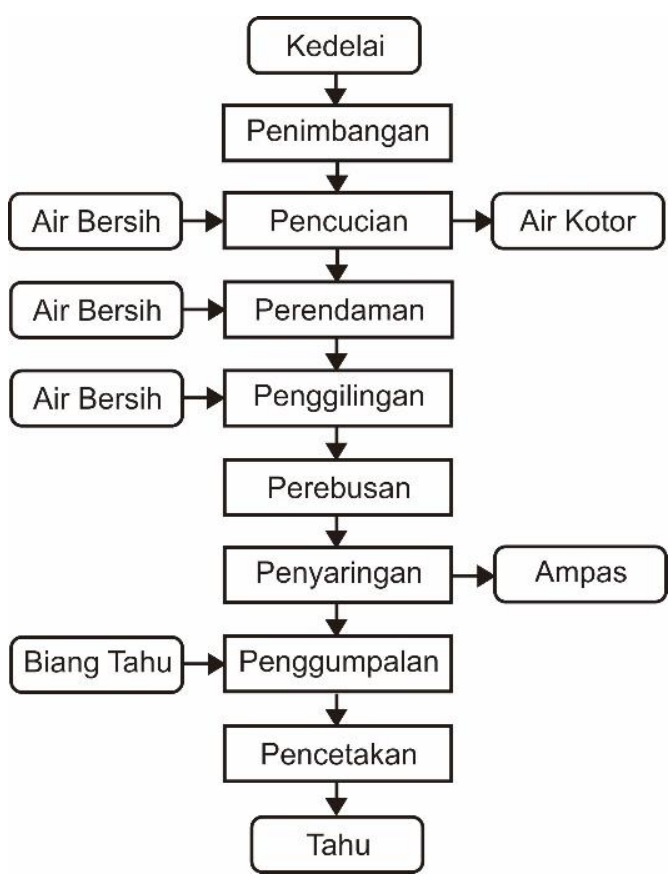

Gambar 11. Bagan Alir Produksi Tahu

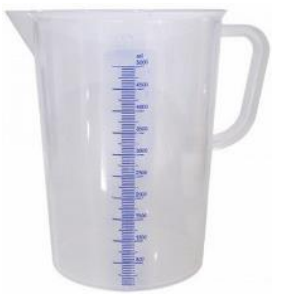

Gambar 12. Alat Ukur BTP

8. Pelabelan pangan

Terdapat 2 subkriteria yang mendapatkan ketidaksesuaian kritis, yaitu label pangan tidak mencantumkan nama produk, daftar bahan yang digunakan, berat bersih/isi bersih, nama IRTP, alamat IRTP, masa kedaluwarsa, kode produksi, nomor P-IRT, klaim kesehatan/klaim gizi. Produk biasanya hanya dibungkus menggunakan plastik tanpa label sehingga otomatis tidak tercantum nama produk, daftar bahan, berat/isi bersih, nama pabrik, alamat pabrik, masa kedaluwarsa, kode produksi, nomor P-IRT, dan klaim gizi. Usulan perbaikan yang diberikan adalah membuat kemasan yang memuat label pangan lengkap dengan nama produk, daftar bahan, berat bersih, nama IRTP, alamat IRTP, masa kedaluwarsa, kode produksi, nomor P-IRT, dan klaim gizi. Kemasan awal dan desain kemasan usulan dapat dilihat pada gambar 13 dan 14 . 


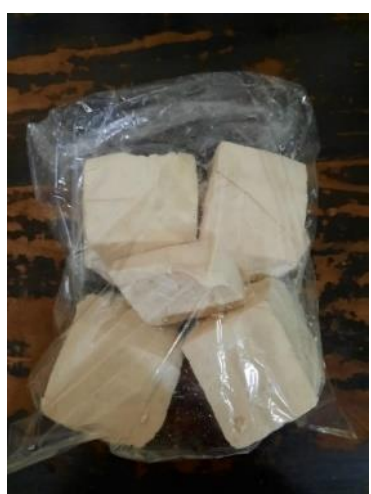

Gambar 13. Kemasan Awal

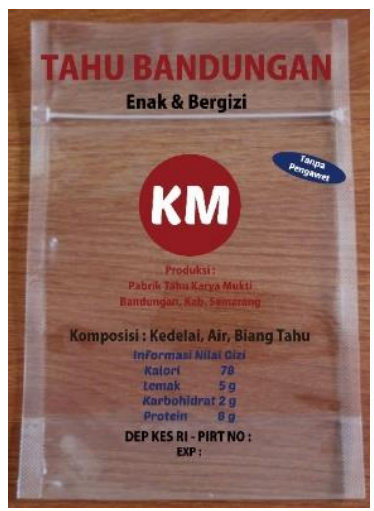

Gambar 14. Desain Kemasan Usulan

9. Pengawasan oleh penanggung jawab

Terdapat 1 subkriteria yang mendapatkan ketidaksesuaian kritis, yaitu IRTP tidak mempunyai penanggung jawab yang memiliki Sertifikat Penyuluhan Keamanan Pangan (PKP). Kemudian ada 1 subkriteria yang mendapatkan ketidaksesuaian serius, yaitu IRTP tidak melakukan pengawasan internal secara rutin, termasuk monitoring dan tindakan koreksi. Pemilik pabrik sendiri belum pernah mengikuti PKP sehingga tidak memiliki sertifikat PKP padahal sertifikat PKP digunakan untuk mendaftar SPP-IRT. Tidak ada tindakan monitoring serta koreksi dari pemilik pabrik apabila ditemukan kesalahan. Usulan perbaikan yang diberikan adalah menganjurkan pemilik pabrik mengikuti PKP yang diadakan oleh Dinas Kesehatan setempat dan melakukan pengawasan terhadap proses produksi secara langsung dengan cara mengobservasi aktivitas produksi. 10. Penarikan produk

Terdapat 1 subkriteria yang mendapatkan ketidaksesuaian kritis, yaitu pemilik IRTP tidak melakukan penarikan produk pangan yang tidak aman. Usulan perbaikan yang diberikan adalah melakukan penarikan produk yang tidak aman dari peredaran jika memungkinkan. Tindakan penarikan pangan menurut Peraturan Kepala BPOM Nomor 22 Tahun 2017 tentang penarikan pangan dari peredaran dilakukan pada saat terjadi kondisi sebagai berikut :

a. Pangan yang telah didistribusikan mempunyai risiko menyebabkan penyakit atau cedera

b. Pangan tidak memenuhi persyaratan keamanan pangan dan atau ketentuan lain yang ditetapkan; dan c. Perlu diambil tindakan untuk melindungi kesehatan masyarakat

Penarikan produk sulit diterapkan untuk Pabrik Tahu Karya Mukti Bandungan dikarenakan dibutuhkan sistem ketertelusuran pangan. Sistem Keterlusuran Pangan adalah kemampuan untuk melacak, menelusuri, mengidentifikasi pegerakan Pangan pada setiap tahapan produksi yang dimulai dari penerimaan bahan baku, pengolahan hingga penyimpanan produk jadi serta tahapan distribusi, termasuk Importir, Distributor, dan Peritel (BPOM, 2017). Ketertelusuran Pangan memuat informasi awal, telusur eksternal (telusur pengiriman), dan telusur internal (telusur proses produksi). Telusur eksternal berisi tanggal pengiriman, jumlah pangan yang dikirim, tujuan pengiriman, dan nomor invoice, penjualan tahu dilakukan di Pasar Bandungan dengan konsumen yang banyak serta berubah-ubah sehingga pemilik kesulitan untuk melakukan telusur eksternal.

11. Pencatatan dan dokumentasi

Terdapat 1 subkriteria yang mendapatkan ketidaksesuaian kritis, yaitu IRTP tidak memiliki dokumen produksi. Pabrik tidak memiliki dokumen produksi sehingga dengan tidak adanya dokumen produksi menjadikan informasi yang tersedia hanya terbatas, sesuai dengan ingatan pemilik dan pekerja. Usulan perbaikan yang diberikan adalah pemilik membuat dokumen produksi sehingga apabila dibutuhkan informasi mengenai produksi dapat langsung mengacu pada dokumen tersebut. Dokumentasi produksi berisi nama produk, deskripsi produk, deskripsi proses, informasi pada label kemasan, bahan pengemas, masa simpan, dan kondisi penyimpanan.

12. Pelatihan Karyawan

Terdapat 1 subkriteria yang mendapatkan ketidaksesuaian kritis, yaitu IRTP tidak memiliki program pelatihan keamanan pangan untuk karyawan. Pelatihan dilakukan secara otodidak dengan cara karyawan baru mengobservasi cara kerja karyawan lama tanpa ada standar prosedur tertentu. Usulan perbaikan yang diberikan adalah membuat program pelatihan keamanan pangan untuk pekerja segera setelah pemilik memperoleh sertifikat PKP. Diharapkan dengan pelatihan keamanan pangan kepada seluruh pekerja, pekerja dapat meningkatkan mutu produk serta melindungi masyarakat melalui pengurangan atau penghilangan bahaya mikroba patogen.

Pada WISE terdapat 3 kriteria yang mengandung subkriteria dengan usulan tindakan prioritas. Kriteriakriteria tersebut yaitu :

\section{Keamanan Mesin Produktif}

Terdapat 1 subkriteria yang mendapatkan usulan tindakan prioritas, yaitu memeriksa, membersihkan, dan memelihara mesin-mesin, termasuk kabel listrik secara teratur. Mesin giling dibersihkan setelah selesai kegiatan menggiling kedelai selesai dengan cara dialiri air, namun jarang dibersihkan menggunakan sabun. Fungsi sabun adalah untuk menghilangkan lendir serta kuman. 
Pemeriksaan mesin giling tidak dilakukan secara teratur, hanya pada saat mesin rusak. Usulan perbaikan yang diberikan adalah membuat jadwal membersihkan dan maintenance mesin penggiling kedelai. Mesin dibersihkan menggunakan sabun dan air setiap selesai bekerja untuk mencegah timbulnya lendir. Maintenance dapat dilakukan dengan mendatangkan teknisi kemudian melatih operator mesin giling untuk melakukan maintenance, sehingga maintenance secara berkala dapat dilakukan mandiri oleh pabrik tanpa perlu mengeluarkan biaya tambahan untuk mendatangkan teknisi. Maintenance dapat dilakukan sebulan sekali, maintenance ini bertujuan untuk mendeteksi kerusakan mesin sedini mungkin sehingga tidak mengakibatkan kerusakan yang lebih besar dan menjadi lebih cepat diatasi.

\section{Fasilitas Kesejahteraan}

Terdapat 2 subkriteria yang mendapatkan usulan tindakan prioritas, yaitu menyediakan perlengkapan pelindung pribadi yang memberikan perlindungan yang memadai serta menyediakan peralatan Pertolongan Pertama pada Kecelakaan (P3K) dan melatih petugas P3K yang memenuhi syarat. Pekerja belum memakai seragam kerja serta perlengkapan perlindungan seperti sepatu boots, sarung tangan, celemek, dan penutup kepala. Perlengkapan perlindungan berfungsi untuk mencegah kontaminasi pangan dari para pekerja sehingga pangan yang dihasilkan aman dikonsumsi. Sudah tersedia perlengkapan $\mathrm{P} 3 \mathrm{~K}$ tetapi tidak ada petugas yang memiliki pengetahuan mengenai pertolongan pertama. Usulan perbaikan yang diberikan adalah memberlakukan peraturan bagi pekerja untuk menggunakan pakaian kerja lengkap seperti seragam kerja, celemek, penutup kepala, penutup hidung dan mulut, sarung tangan, serta sepatu boots, kemudian melatih salah satu pekerja untuk menjadi petugas $\mathrm{P} 3 \mathrm{~K}$ dengan mendatangkan instruktur dari PMI untuk memberikan pelatihan Pertolongan Pertama (PP).

3. Organisasi Pekerjaan

Terdapat 1 subkriteria yang mendapatkan usulan tindakan prioritas, yaitu menetapkan kebijakan Kesehatan dan Keselamatan Kerja (K3) dan menyediakan pelatihan keselamatan dan kesehatan yang memadai bagi semua pekerja. Pabrik belum memiliki kebijakan K3 serta pelatihannya kepada pekerja sehingga pekerja masih belum memahami pentingnya implementasi K3 di area kerja. Usulan perbaikan yang diberikan adalah membuat kebijakan K3 yang dapat dijalankan oleh seluruh pekerja sehingga dapat mengurangi risiko kecelakaan kerja. Kebijakan K3 menjadi ketentuan dasar dalam membangun Sistem Manajemen Keselamatan dan Kesehatan Kerja (SMK3) di area kerja dan merupakan suatu komitmen pemilik pabrik untuk menjamin K3 seluruh pekerja serta pihak lain yang terlibat dengan aktivitas operasi pabrik tersebut. Contoh Kebijakan K3 dapat dilihat pada gambar 15.

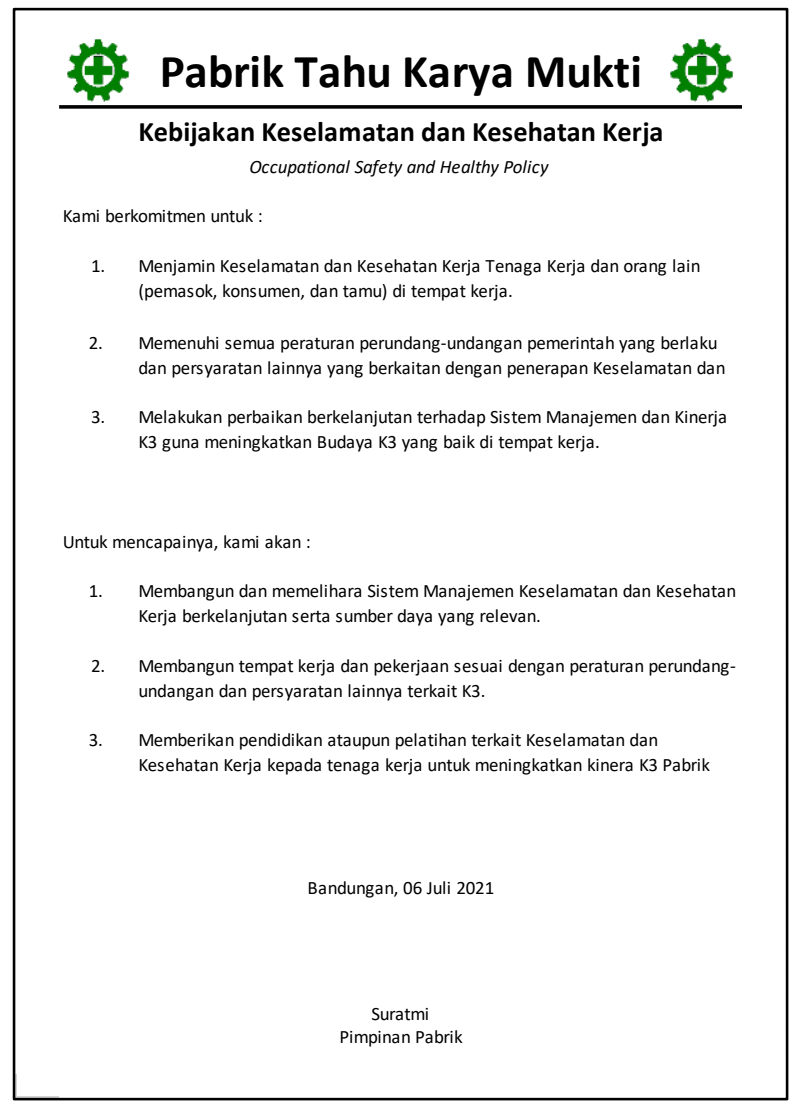

Gambar 15. Contoh Kebijakan K3

\section{Kesimpulan}

Pengukuran pemenuhan standar GMP dan WISE yang dilakukan pada Pabrik Tahu Karya Mukti Bandungan menghasilkan 12 kriteria GMP yang mengandung 22 subkriteria dengan ketidaksesuaian kritis dan serius serta 3 kriteria WISE yang mengandung 4 subkriteria dengan usulan tindakan prioritas.

Usulan perbaikan diberikan pada subkriteria yang mendapat ketidaksesuaian kritis dan serius pada GMP serta subkriteria yang mendapat usulan tindakan prioritas pada WISE. Perbaikan yang diusulkan adalah membuat monitoring kebersihan, menempelkan pengingat, menyediakan saran cuci tangan lengkap, menempelkan prosedur cuci tangan yang benar, menempel tanda peringatan pada pintu toilet, menempel peraturan wajib cuci tangan dan penggunaan pakaian kerja, membuat program higiene dan sanitasi, menutup tungku masak, menyimpan peralatan produksi, pembuatan catatan penggunaan BTP, membuat bagan alir produksi, penandaan BTP, menyediakan alat ukur BTP, pembuatan desain kemasan, anjuran mengikuti PKP, pengawasan proses produksi, penarikan produk yang tidak aman, membuat dokumen produksi, membuat program PKP untuk karyawan, membuat jadwal membersihkan dan maintenance mesin, melatih Pertolongan Pertama, serta membuat kebijakan K3. 


\section{Daftar Pustaka}

BPOM. (2012). Peraturan Kepala Badan Pengawas Obat dan Makanan Republik Indonesia Tentang Cara Produksi Pangan yang Baik untuk Industri Rumah Tangga., Pub. L. No. HK.03.1.23.04.12.2206.

http://standarpangan.pom.go.id/dokumen/peraturan /2012/Perka_BPOM_No_HK.03.1.2

3.04.12.2206_Tahun_2012_tentang_CPPB _PIRT.pdf. (Diakses 15 Juni 2021)

BPOM. (2017). Peraturan Kepala Badan Pengawas Obat dan Makanan Republik Indonesia Tentang Penarikan Pangan dari Peredaran. https://bikinpabrik.id/wpcontent/uploads/2019/03/PerkaNo.22_2017_Recall-Pangan.pdf. (Diakses 15 juni 2021)

Damarasri, D. R., Partiwi, S. G., \& Gunawan, J. (2013). Penerapan Good Manufacturing Practice dan Work Improvement in Small Enterprise pada Usaha Kecil dan Menengah untuk Pemenuhan Standar Kesehatan (Studi Kasus : UKM Tempe Tenggilis Mejoyo Surabaya). Tugas Akhir. Institut Teknologi Sepuluh November (ITS).

Hermansyah, Muhammad. dkk. (2013). Hazard Analysis And Critical Control Point (HACCP) Produksi Maltosa Dengan Pendekatan Good Manufacturing Practice (GMP). Jemis Vol. 1 No. 1

International Labour Organization. (2015). Daftar Periksa Pembinaan Peningkatan Keselamatan dan Kesehatan Kerja pada Usaha Kecil dan Menengah dengan Metode Pelatihan Partisipasi Aktif. Jakarta: Kementerian Ketenagakerjaan Republik Indonesia.

Islami, S. B., \& Partiwi, S. G. (2013). Analisis Penilaian Penerapan Kesehatan dan Keselamatan Kerja pada Industri Kecil dan Menengah dengan Menggunakan Metode WISE. Tugas Akhir. Institut Teknologi Sepuluh November (ITS).

Kementerian Koperasi dan UKM. (2005). Peran Usaha Mikro, Kecil dan Menengah Dalam Pembangunan Ekonomi Nasional. Surabaya

Koswara, S. (2011). Nilai Gizi, Pengawetan dan Pengolahan Tahu. http://www.ebookpangan.com

Mubaranto H. (2016). Strategi pengembangan industri kecil tahu dalam rangka pembangunan ekonomi daerah Kabupaten Tegal. Tesis. Institut Pertanian Bogor

Santoso, H.B. (1993). Pembuatan Tempe dan Tahu Kedelai. Yogyakarta: Kanisius

Sarwono, S., \& Saragih, Y.P. (2003). Membuat Aneka Tahu. Jakarta: Penebar Swadaya.

Shurtleff, W., \& Aoyagi, A. (2001). Tofu and Soymilk Production: A Craft and Technical Manual. Soyinfo Center

Thaheer, H. (2005). Sistem Manajemen HACCP (Hazard Analysis Critical Control Points). Jakarta : Bumi Aksara. 